\title{
Genetic consequences of population subdivision: the marsupial Micoureus paraguayanus (Mammalia: Didelphimorphia) as a case study
}

\author{
Daniel Brito
}

Departamento de Ecologia, Universidade Federal de Goiás. Caixa Postal 131, 74001-970 Goiânia, Goiás, Brasil. E-mail: brito.dan@gmail.com

\begin{abstract}
Habitat fragmentation may cause population subdivision, affecting genetic variation, leading to heterozygosity loss and increased inbreeding, and contributing to population extinction. However, some genetic models have shown that under some conditions, population subdivision can favor heterozygosity and allelic diversity, and small populations may adapt to inbreeding. Here I investigate the relationship between population subdivision and genetic diversity for the marsupial Micoureus paraguayanus (Tate, 1931) using the program Vortex. Hypothetical populations of 100 and 2000 individuals were partitioned into 1, 2, 5 or 10 populations that were linked by varying rates of dispersal and also by sex-biased dispersal. Results suggested that heterozygosity and allelic diversity declined rapidly when a population was subdivided. Genetic and demographic stochasticity diminished the effectiveness of selection against recessive lethal alleles. Dispersal partly reversed the impacts of population subdivision. However, even high rates of dispersal did not eliminate demographic fluctuations or prevent extinction. Although gene flow largely prevented genetic divergence between populations, dispersal did not prevent heterozygosity from being lost more rapidly in subdivided populations than in single populations of equivalent total size. The dynamics of small, fragmented populations were critically dependent on interactions between demographic and genetic processes. Populations of M. paraguayanus may have to be relatively large and continuous to avoid significant losses of genetic diversity.

KEYWORDS. Genetic drift; genetic load; habitat fragmentation; inbreeding; metapopulation; population viability analysis.
\end{abstract}

The Atlantic Forest is one of the world's 34 biodiversity hotspots and one of the most devastated and highly threatened ecosystems on the planet (Fonseca 1985, Myers et al. 2000, MitTermeier et al. 2005). Habitat fragmentation and loss have severely altered most of the Atlantic Forest, and only about $7 \%$ of its original area is left (CÂmara 2003, Hirota 2003). Habitat loss and fragmentation affect extinction rates, population sizes and dispersal patterns (FAHrig \& Merriam 1994), being among the greatest threats to the viability of wildlife populations (SHAFFER 1981, Soulé 1987, Simberloff 1988, Ledig 1992, Soulé \& Mills 1998, Gibbs 2001, ReEd 2004). Therefore, it is vital to understand how extinction rates in an ensemble of smaller populations compare with that of one large population of equivalent size (REED 2004). The stochastic factors that impact small populations are synergistic, potentially leading to an extinction vortex (GILPIN \& Soulé 1986, Brito \& Fernandez 2000a, ReEd 2004). Increased extinction risk in smaller populations might make it seem obvious that fragmenting continuous habitats with larger population sizes into multiple habitat remnants with smaller populations would increase the probability of extinction (ReED 2004). Because genetic and demographic processes interact in their effects on viability, considering them in isolation may underestimate the severity of the threats that populations are subject to, and even lead to the development of ineffective or counter-productive recommendations for management.

The effects of habitat fragmentation on population genetics can be complex. For example, some authors argue that archipelagos of refuges might be the optimal design for the conservation of genetic variation (e.g. BoeckLEN 1986), while others include fragmentation among the causes of extinction (e.g. Gilpin \& Soulé 1986, Reed 2004). Some authors caution that inbreeding might impair conservation efforts (e.g. LACY 1993a, 1997, Mills \& Smouse 1994, Frankham 1998, Soulé \& Mills 1998, Keller \& Waller 2002), while others suggest it can be alleviated and purged from small, isolated populations (e.g. Templeton \& Read 1984, Brewer et al. 1990, Ballou 1997, Lacy \& Ballou 1998, Byers \& Waller 1999, Miller \& Hedrick 2001). However, deliberate inbreeding to purge inbreeding depression may be a risky strategy, because reduction in fitness may result in extinction (Hedrick \& Kalinowski 2000, Hedrick 2001). Even if the population persists, detrimental alleles may be permanently fixed. This could lower fitness, and genetic variation in other loci may be lost (Hedrick \& KaLINOwski 2000, Hedrick 2001).

Genetic diversity is positively related to population size (Frankham 1996). In small populations, changes in allele frequencies are more strongly determined by random genetic drift

() 2009 Sociedade Brasileira de Zoologia | www.sbzoologia.org.br | All rights reserved. 
than by natural selection (LACY 1987). This results in lower heterozygosity and rapid loss of alleles (LACY 1987, 1997, HedRICK 2001, Keller \& WALler 2002). Reduced heterozygosity can impact population demography and viability by diminishing other aspects of fitness, such as fecundity, mating success, disease resistance and competitive ability (AlLENDORF \& LEARY 1986, RaLLS et al. 1988, LACY 1993a, Miller \& Hedrick 1993). Allele loss may reduce flexibility for future adaptive evolution (VAN VALEN 1973, Franklin 1980, Brito \& Fernandez 2000a). Although population subdivision results in faster genetic drift within habitat patches, some of the genetic diversity that is lost from populations within patches is converted into between-patch diversity (LACY 1987). As a result, genetic diversity within a metapopulation may be greater than that retained within a single population of comparable total size (BoECKLen 1986, LACY 1987).

Intentional, managed fragmentation of continuous populations, with low dispersal among populations has been recommended as a strategy to preserve genetic variation (BoECKLEN 1986, LACY 1987). However, genetic decay, manifest in both inbreeding depression and loss of evolutionary flexibility, may cause the demise of small populations (GILPIN \& Soulé 1986, Lacy 1993a, Brito \& Fernandez 2000a). Therefore, it is important to understand under what conditions fragmentation causes deleterious genetic consequences, and under what conditions such effects can be beneficial.

This study uses population viability analysis (PVA) as a tool to model genetic aspects in response to population subdivision for Micoureus paraguayanus (Tate, 1931), Didelphidae. Here I assess the impacts of fragmentation on genetic changes within populations of $M$. paraguayanus that were divided into metapopulations of varying size and dispersal levels.

\section{MATERIAL AND METHODS}

Micoureus paraguayanus is an endemic marsupial of the Atlantic Forest (GARDNER 2005). This small ( $\approx 130 \mathrm{~g})$, nocturnal, largely arboreal, solitary and polygynous didelphid is found in mature and secondary forest (PASSAMANI 1995, 2000, Grelle 2003). The species favors dense viny vegetation with many palm trees (Moraes \& Chiarello 2005b). M. paraguayanus feeds on arthropods, fruits and nectar (Leite et al. 1994, CARVALHo et al. 1999, CÁCERes et al. 2002, Pinheiro et al. 2002, Fernandez et al. 2006). Demographic data of $M$. paraguayanus that were input to Vortex (Tab. I) are based on a wide range of field studies (Pires \& Fernandez 1999, Pires et al. 1999, 2002, Brito \& Fernandez 2000b, 2002, Quental et al. 2001, Fernandez et al. 2003, 2006, Brito \& Grelle 2004, Moraes \& Chiarello 2005a, b, Brito \& Da Fonseca 2006, 2007, Goulart et al. 2006). The average size of its home range is estimated at 0.65 ha, home ranges of males were overlapping with those of females (Pires \& Fernandez 1999, Pires et al. 1999). Adult females and males first breed at 6 months of age with a maximum of 11 young per litter. The longest lifespan recorded for the species in the wild is about 24 months. PIrEs et al. (2002) estimated a dispersal rate of $1.2 \%$ between Atlantic Forest fragments in south-
Table I. Biological and ecological attributes of the long-furred woolly mouse opossum M. paraguayanus used as input to Vortex, with a time step of two months.

\begin{tabular}{ll}
\hline \multicolumn{1}{c}{ Parameter } & \multicolumn{1}{c}{ Value } \\
\hline Breeding system & Polygynous \\
Maximum age & 12 \\
Minimum female breeding age & 3 \\
Minimum male breeding age & 3 \\
Sex ratio (\%males) & $50 \%$ \\
\% females producing litters & $16.67 \%$ \\
\% litter size 1 & $0.10 \%$ \\
\% litter size 2 & $1.40 \%$ \\
\% litter size 3 & $15.50 \%$ \\
\% litter size 4 & $83 \%$ \\
\% males in breeding pool & $100 \%$ \\
Female mortality & $8.72 \%$ \\
Male mortality & $8.72 \%$ \\
Density dependence & nil \\
Deterministic population growth (lambda) & 1.08 \\
Generation time (years) & 1.08 \\
Environmental variation as SD (fluctuation & \\
across years) & \\
In fecundity & $10 \%$ of the mean \\
In mortality & $10 \%$ of the mean \\
Environmental variation, survival and & Concordant \\
reproduction & \\
\hline & \\
\hline
\end{tabular}

eastern Brazil for M. paraguayanus, crossing up to $800 \mathrm{~m}$ of matrix habitat. Pires \& Fernandez (1999) studied a metapopulation of M. paraguayanus in Atlantic Forest remnants and observed that movements among forest patches were made by adult males, during the reproductive season, and that the vast majority of individuals (males and females) were restricted to a single fragment during their whole life. There is evidence for male-only dispersal in M. paraguayanus (Pires \& Fernandez 1999, Pires et al. 2002), and in this case, local extinctions cannot be naturally replaced by recolonization. A study on the frequency of movements of small mammals among Atlantic Forest fragments in southeastern Brazil estimated an inter-fragment movement rate of $1.2 \%$ for M. paraguayanus (PIREs et al. 2002), a value quite similar and within the range of the scenarios modeled in the present analysis. However, there is evidence that females are also capable of dispersing through grassland matrix, at least to some extent (Moraes \& Chiarello 2005a).

The computer simulation package Vortex version 9.57 was used. Vortex is a Monte Carlo simulation of the effects of deterministic forces as well as demographic, environmental and ge- 
netic stochasticity and catastrophes on the dynamics of wildlife populations (LACY 1993b, 2000, MilLer \& LACY 2005). This package is one of the most often used for PVA focusing endangered populations, including in workshops with officers from conservation and land management agencies (LINDENMAYER et al. 1995).

A simulation study suggested that population sizes of 100 and 2000 individuals were necessary for M. paraguayanus' populations to achieve demographic and genetic viability, respectively, being indicated as quasi-extinction threshold sizes for the species (BRito \& DA Fonseca 2006). For each of the metapopulation sizes modeled (100 and 2000), four levels of subdivision (1, 2, 5 and 10 populations), three rates of dispersal $(0,0.01,0.05)$ and the role of sex-biased dispersal (both sexes dispersing or only males dispersing) were examined, giving a total of 48 scenarios. I completed 500 simulations for each scenario.

Because we do not have detailed information on the genetics of M. paraguayanus, particularly the frequency of deleterious alleles, I used the reported median of 3.14 lethal equivalents per individual, based on a survey of the effects of inbreeding on mammalian species (Ralls et al. 1988). Genetic changes in the simulated populations were assessed using several measures: (1) the number of alleles remaining from the initial founder's alleles, (2) the genetic load of lethal alleles, expressed as the ratio of the number of lethal alleles to the number of viable alleles, and (3) the gene diversity or expected heterozigosity (He).

Time scale is of paramount importance in extinction studies (Armbruster et al. 1999, Frankham \& Brook 2004). The species' short generation time ( 0.95 years) allowed the choice of a 100 year time horizon and therefore avoid the problem of unrealistic predictions due to incompatibility between time frame used and species generation time (ARMBruster et al. 1999). Such time horizon considered in our analyses (100 years) is in accordance with economic and political issues, and management practices. I considered genetic viability to occur when the population maintained $90 \%$ or more than its original genetic diversity during the 100-year period used in the analyses (Foose et al. 1986, Foose 1993).

\section{RESULTS}

\section{Impacts of metapopulation size}

Genetic drift caused losses of gene diversity in both the simulated populations sizes (100 and 2000 individuals) (Figs 1 and 2). The loss of gene diversity was faster in smaller populations. However, for the larger population size, such loss stayed within the threshold of $90 \%$, suggesting genetic viability. Allelic diversity was rapidly lost from all populations modeled (Figs 3 and 4). Selection removed almost all of the genetic load of recessive lethal alleles for the smaller population (Fig. 5). The loss of lethal alleles was slightly slower for larger populations (Fig. 6). With carrying capacities of 100 to 2000, inbreeding over the course of approximately 95 generations was sufficient to expose lethal recessive alleles as homozygotes that could be purged by selection.

\section{Impacts of population subdivision}

Increasing population subdivision led to a more rapid decline in gene diversity, particularly for the metapopulation size of 100 individuals (Figs 1 and 2). This was expected given the small population sizes in each habitat fragment. Moreover, small isolated populations undergo greater demographic fluctuations (BRITO \& DA FONSECA 2007), which would contribute to further decreases in effective population size and more rapid genetic drift (Lande \& Barrowclough 1987). Gene diversity declined more rapidly in metapopulations of 100 individuals than in undivided populations of equivalent size (Fig. 1). For the larger population size (2000 individuals), gene diversity declined at the same rate in metapopulations as in the non-fragmented populations (Fig. 2). Genetic drift caused by increased demographic fluctuations in the small populations offsets the potential for population subdivision to preserve gene diversity. In addition, gene diversity declined rapidly in scenarios with 100 animals after the populations began suffering extinctions. The results suggest a subdivision threshold size, below which the effects of demographic stochasticity and extinction surpass any benefits gained from inter-population gene diversity maintained by genetic drift. For populations with 100 individuals, the number of alleles also declined more rapidly in scenarios with metapopulations than in scenarios with undivided populations (Fig. 3). A decline in allelic diversity in metapopulations was detected even before extinctions occurred. The loss of alleles resulting from the demographic instability of small populations occurred earlier than the decline in gene diversity. For the population size of 2000, the rate of decline was similar in metapopulations and undivided populations (Fig. 4). Population subdivision led to a reduction of the proportion of alleles that were recessive lethals (Figs 5 and 6). Both viable and lethal alleles were lost rapidly from the populations. However, selection against homozygotes for the recessive lethal alleles may have caused more rapid losses of lethal alleles.

\section{Impacts of dispersal}

Migration among populations slowed the negative effects of population subdivision (Figs 1 and 2). Gene diversity declined more slowly in metapopulations that were connected by dispersal than in totally isolated metapopulations (Figs 1 and 2). In metapopulations of 2000 individuals, a dispersal rate of $1 \%$ effectively prevented populations from losing gene diversity more rapidly than an undivided population (Fig. 2). This dispersal rate also limited the extent of genetic diversity among populations (Fig. 2). Conversely, in metapopulations of 100 animals, even 5\% dispersal rate did not fully reverse the effects of subdivision (Fig. 1). Losses of gene diversity in highly subdivided populations (100 individuals subdivided into 2, 5 or 10 populations) that were connected by high rates of dispersal exceeded the losses from undivided populations. Many populations suffered extinction, and genetic losses resulted from a failure of dispersal to demographically stabilize the popula- 

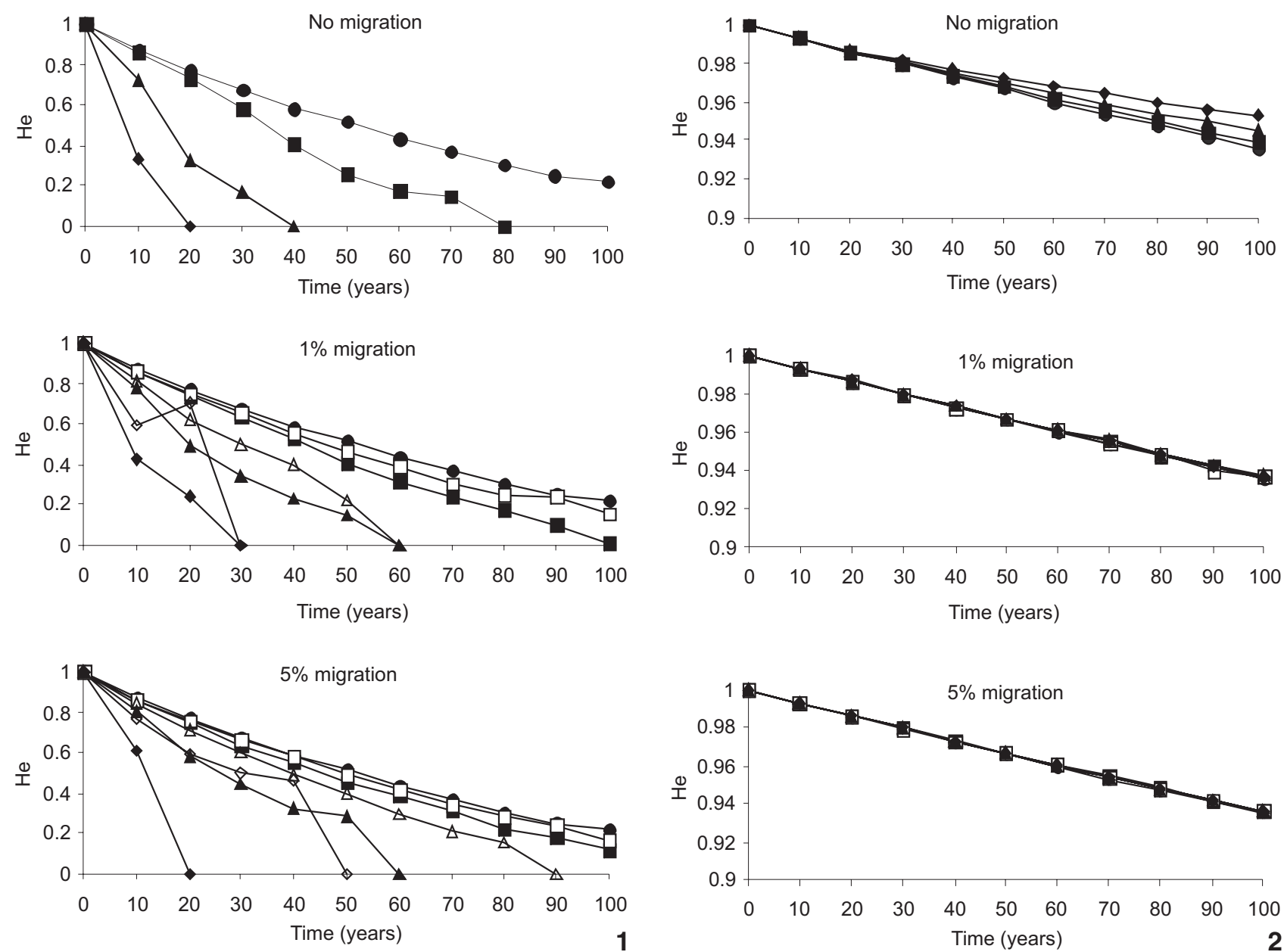

Figures 1-2. Loss of gene diversity over 100 years from metapopulations of $M$. paraguayanus with carrying capacity of 100 (1) and 2000 (2), divided into $1(\bigcirc), 2(\square), 5(\triangle)$ or $10(\diamond)$ subpopulations connected by different migration rates $(0 \%, 1 \%$ or $5 \%)$ and by equal dispersal by both sexes (white) and male-biased dispersal (black).

tions. Increased dispersal led to more alleles within populations (Figs 3 and 4), because immigrants periodically introduced new alleles into the populations. In the early years of the simulations, dispersal resulted in decreases in the number of alleles preserved within the metapopulation, because it reduced the ability of population subdivision to ensure the protection of different alleles in each population. However, in the later years of the simulations, dispersal resulted in more alleles being maintained in the metapopulation, presumably because the populations suffered fewer extinctions and the metapopulation remained larger than in scenarios with no dispersal. Dispersal reduced the effectiveness of removal of recessive lethal alleles from metapopulations by selection (Figs 5 and 6). Animals were less likely to mate with relatives in scenarios with high rates of dispersal among populations. This lower inbreeding helped to preserve gene diversity (Figs 1 and 2), but reduced the frequency of selection against recessive lethal alleles. The higher the dispersal rate, the lower the reduction in the recessive lethal alleles (Figs 5 and 6). In scenarios with small metapopulations (100 individuals) and high rates of dispersal, the few extant metapopulations comprised only one or two populations, which were highly inbred and were likely on the verge of extinction.

\section{Impacts of sex-biased dispersal}

In small metapopulations, scenarios simulating dispersal by both sexes resulted in greater preservation of gene diversity than scenarios where only males were capable of dispersal among populations (Fig. 1). However, in scenarios with only males dispersing, populations are more isolated, enhancing inbreeding. As a result, recessive lethal alleles are more rapidly eliminated from the population when compared to scenarios where both sexes are capable of dispersing among populations (Fig. 5). 

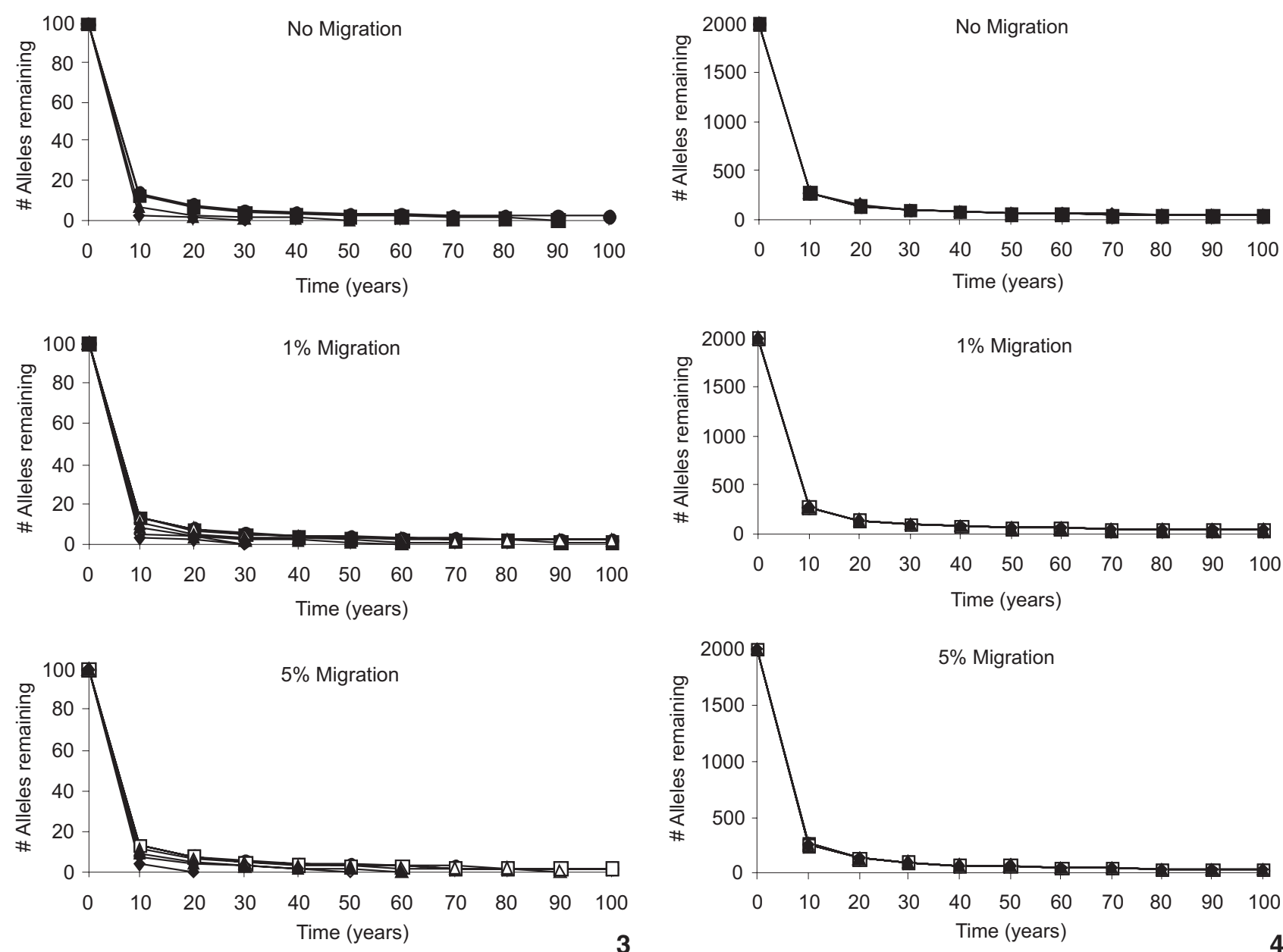

Figures 3-4. Loss of gene diversity over 100 years from metapopulations of $M$. paraguayanus with carrying capacity of 100 (3) and 2000 (4), divided into $1(\bigcirc), 2(\square), 5(\triangle)$ or $10(\diamond)$ subpopulations connected by different migration rates $(0 \%, 1 \%$ or $5 \%)$ and by equal dispersal by both sexes (white) and male-biased dispersal (black).

\section{DISCUSSION}

The effects of population size, population subdivision, and dispersal on genetic diversity can be strongly influenced by interactions between demographic and genetic processes. In theory, population subdivision can lead to a better retention of gene diversity than in a panmitic population (BOECKLEN 1986, LACY 1987). This is because some of the gene diversity that is lost from within populations is protected in the form of between population gene diversity (LACY \& LindENMAYER 1995). However, such a mechanism depends critically on the demographic stability of populations. The smaller populations that result from the process of subdivision are subjected to greater demographic stochasticity, which causes greater fluctuations in population size (LACY \& Lindenmayer 1995, BRito \& DA FonsecA 2007). Subdivided populations would be expected to lose genetic variation due to random drift and gene diversity rarely matched the levels in panmitic populations.

Metapopulation structure may make it difficult for natural selection to purge deleterious alleles that cause inbreeding depression (ЕвеRт et al. 2002, Ives \& WhiтLock 2002). If dispersal is low, populations remain genetically distinct and weakly selected-against deleterious alleles can reach high frequencies in local populations, setting stage for inbreeding depression. The semi-isolation of populations means that they are likely to differ with respect to the deleterious alleles they harbour. Therefore, benefits accrue among the hybrid offspring of residents and immigrants, because the bad effects of any recessive alleles they receive from one parent are likely to be masked by the alleles from the other parent (IVEs \& WHITLOCK 2002). Metapopulation structure, habitat loss and fragmentation, and environmental stochasticity can be expected to greatly accelerate the accumulation of mildly deleterious mutations (LANDE 1995, Higgins \& 

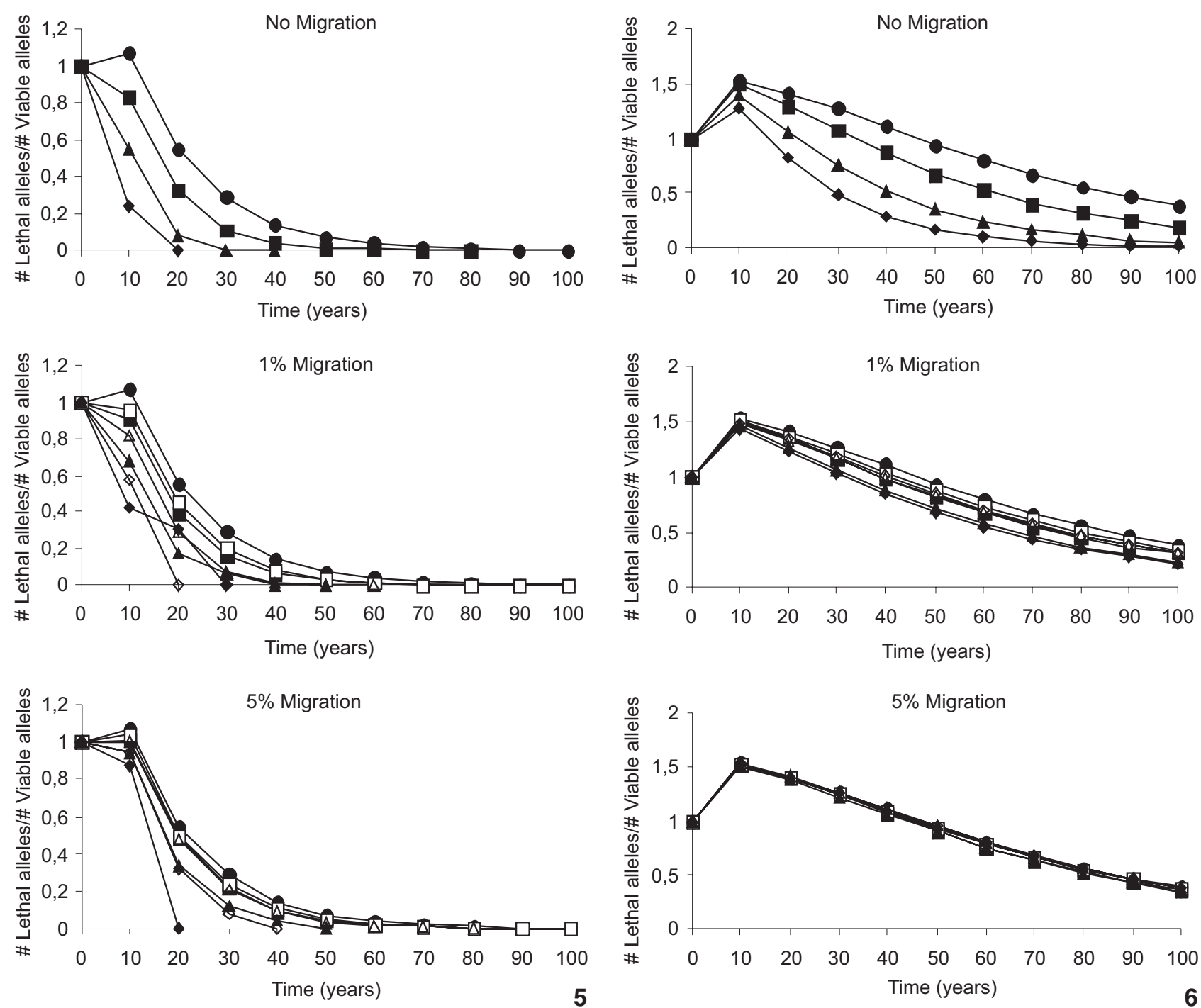

Figure 5. Reduction in the genetic load over 100 years from metapopulations of $M$. paraguayanus with carrying capacity of 100 (5) and $2000(6)$, divided into $1(\bigcirc), 2(\square), 5(\triangle)$ or $10(\diamond)$ subpopulations connected by different migration rates $(0 \%, 1 \%$ or $5 \%)$ and by equal dispersal by both sexes (white) and male-biased dispersal (black).

LyNCH 2001), lowering the genetic effective size to such a degree that even large metapopulations may be at risk of extinction (LANDE 1995, Higgins \& LYNCH 2001). Because of mutation accumulation, viable metapopulations may need to be far larger and better connected than would be required under just demographic stochasticity (Higgrns \& LyNCH 2001). From a genetic perspective, a metapopulation may be much more vulnerable to extinction than a population of the same overall number of individuals (Higgins \& Lynch 2001). Brito \& Fernandez (2000b) estimated that genetic stochasticity and inbreeding depression might be one of the most serious threats to the long-term persistence of a M. paraguayanus metapopulation composed of very small popu- lations in southeastern Brazil. In that case, heterozygosity was proposed as one management variable to be used to measure the relative contribution of each population to the viability of the metapopulation (Brito \& Fernandez 2002).

Fluctuations in population size due to demographic stochasticity may negate the presumed benefits of subdivision in preserving gene diversity. Population extinctions eliminate the inter-population component of gene diversity, and metapopulation gene diversity may approach that of the highly inbred populations (LACY \& LindenMAYER 1995). Bottlenecked populations are expected to rapidly lose rare alleles (MARUYAMA \& Fuerst 1985, Allendorf 1986, Fuerst \& Maruyama 1986). Because 
different alleles can be protected in the various populations (BoeCKLEN 1986, LACY 1987), population subdivision may help to preserve metapopulation gene diversity. However, the results indicated that alleles were lost as fast, or faster, from subdivided populations than from single populations of the same initial total size. Even when there were no extinctions, alleles were lost more rapidly in subdivided populations. This probably occurred as a result of the smaller total population size maintained in the fragmented and greater demographic stochasticity. Eventually, a group of isolated populations would be expected to retain more alleles and gene diversity than would a panmitic population, as different alleles would become fixed in the populations while a single allele would remain in a panmitic population, in the absence of mutation. However, the approach to such an equilibrium is so slow (BOECKLEN 1986, VARIO et al. 1986) that the equilibrium result is almost irrelevant to conservation actions dealing with the present crisis of biodiversity decline. As the case for gene diversity, the hypothetical advantage of subdivision in protecting allelic diversity is reversed if populations go extinct.

Low rates of dispersal, of approximately one individual per generation, are commonly considered to be effective for preventing deleterious losses of genetic diversity in subdivided populations (LACY 1987). However, several authors suggest that more than one migrant per generation may be necessary to achieve genetic viability (Mills \& Allendorf 1996, Vucetich \& WAITE 2000). The one migrant per generation rule only applies when effective population size equals actual population size (Vucetich \& Waite 2000). As effective population size is usually less than actual population size (FrankHAM 1995), the number of migrants required for genetic viability should exceed one. Mills \& Allendorf (1996) suggested that a minimum of one and a maximum of 10 migrants per generation would be an appropriate general estimate for genetic purposes. VucETICH \& WaITE (2000) demonstrated that even more than 20 migrants per generation may be needed to maintain genetic diversity. Dispersal in the scenarios of the present study was an order of magnitude more than one animal per generation. However, our results showed that such migration was relatively ineffective. The large demographic fluctuations that occur in highly subdivided populations can significantly depress effective population size (MARUYAMA \& KimURa 1980). Increased dispersal in our models reduced the rate of gene and allelic diversity loss. However, even at the highest rates of dispersal, gene and allelic diversity were always lost as fast, or faster, from subdivided populations than from panmitic populations of the same initial total size. In our scenarios, one migrant per generation is not enough to rescue populations from genetic erosion.

It has been suggested that a careful balance between fragmentation and dispersal can achieve simultaneously the benefits of both population isolation and genetic mixing. However, the results presented here suggest that within a highly fragmented population linked by dispersal, heterozygosity may be lost rapidly due to the small size and instability of populations. The small populations might not be sufficiently robust to survive the intense selection needed to remove the genetic load, and alleles could be lost due to the genetic homogenization imparted by dispersing individuals. For many populations in the Atlantic Forest, including those of M. paraguayanus, the most effective conservation solution to fragmentation might be to restore large areas of habitat capable of supporting populations that are demographically and genetically stable. Until recently, there were no genetic studies for $M$. paraguayanus, only modelling approaches (e.g. Brito \& Fernandez 2000b, 2002). However, Rodrigues et al. (2006) have recently isolated and characterized five microsatellite loci for M. paraguayanus. This would provide a useful tool for studying genetic diversity and the consequences of habitat fragmentation on population genetic structure for this species.

\section{ACKNOWLEDGMENTS}

I would like to thank Gustavo A.B. da Fonseca, Carlos E.V. Grelle, José E.C. Figueira, Cláudia M. Jacobi, Flávio H.G. Rodrigues and Adriano G. Chiarello for critical comments and suggestions on the manuscript.

\section{LITERATURE CITED}

Allendorf, F.W. 1986. Genetic drift and the loss of alleles versus heterozygosity. Zoo Biology 5: 181-190.

Allendorf, F.W. \& R.F. Leary. 1986. Heterozygosity and fitness in natural populations of animals, p. 57-76. In: M.E. Soulé (Ed.). Conservation biology: the science of scarcity and diversity. Sunderland, Sinauer Associates, 584p.

Armbruster, P.; P. Fernando \& R. Lande. 1999. Time frames for population viability analysis of species with long generations: an example with Asian elephants. Animal Conservation 2: 69-73.

BALLOU, J.D. 1997. Ancestral inbreeding only minimally affects inbreeding depression in mammalian populations. Journal of Heredity 88: 169-178.

BoeckLen, W.J. 1986. Optimal reserve design of nature reserves: consequences of genetic drift. Biological Conservation 38: 323-338.

Brewer, B.A.; R.C. Lacy; M.L. Foster \& G. Alaks. 1990. Inbreeding depression in insular and central populations of Peromyscus mice. Journal of Heredity 81: 257-266.

Brito, D. \& F.A.S. Fernandez. 2000a. Dealing with extinction is forever: understanding the risks faced by small populations. Journal of the Brazilian Association for the Advancement of Science 52: 161-170.

Brito, D. \& F.A.S. Fernandez. 2000b. Metapopulation viability of the marsupial Micoureus demerarae in small Atlantic Forest fragments in south-eastern Brazil. Animal Conservation 3: 201-209.

Brito, D. \& F.A.S. Fernandez. 2002. Patch relative importance to metapopulation viability: the Neotropical marsupial Micoureus demerarae as a case study. Animal Conservation 5: 45-51. 
Brito, D. \& G.A.B. DA Fonseca. 2006. Evaluation of minimum viable population size and conservation status of the longfurred woolly mouse opossum Micoureus paraguayanus: an endemic marsupial of the Atlantic Forest. Biodiversity and Conservation 15: 1713-1728.

Brito, D. \& G.A.B. DA Fonseca. 2007. Demographic consequences of population subdivision on the long-furred woolly mouse opossum (Micoureus paraguayanus) from the Atlantic Forest. Acta Oecologica 31: 60-68.

Brito, D. \& C.E.V. GrelLE. 2004. Effectiveness of a reserve network for the conservation of the endemic marsupial Micoureus travassosi in Atlantic Forest remnants in southeastern Brazil. Biodiversity and Conservation 13: 2519-2536.

Byers, D.L. \& D.M. Waller. 1999. Do plant populations purge their genetic load? Effects of population size and mating history on inbreeding depression. Annual Review of Ecology and Systematics 30: 479-513.

Cáceres, N.C.; I.R. Ghizoni \& M.E. Graipel. 2002. Diet of two marsupials, Lutreolina crassicaudata and Micoureus demerarae, in a coastal Atlantic Forest island of Brazil. Mammalia 66: 331-340.

CÂmara, I.G. 2003. Brief history of conservation in the Atlantic Forest, p. 31-42. In: C. Galindo-Leal \& I.G. CÂmara (Eds). The Atlantic Forest of South America: biodiversity status, threats and outlook. Washington, Island Press, 408p.

Carvalho, F.M.V.; P.S. Pinheiro; F.A.S. Fernandez \& J.L. Nessimian. 1999. Diet of small mammals in Atlantic Forest fragments in southeastern Brazil. Revista Brasileira de Zoociências 1: 91-101.

Ebert, D.; C. HaAg; M. Kirkpatrick; M. Riek; J.W. Hottinger \& V.I. PAJUnEN. 2002. A selective advantage to immigrant genes in a Daphnia metapopulation. Science 295: 485-488.

Fahrig, L. \& G. Merriam. 1994. Conservation of fragmented populations. Conservation Biology 8: 50-59.

Fernandez, F.A.S.; C.S. Barros \& M. Sandino. 2003. Biased sex ratios in populations of the woolly mouse opossum Micoureus demerarae in Atlantic Coastal Forest fragments. Natureza e Conservação 1: 78-84.

Fernandez, F.A.S.; A.S. Pires; F.M.V. Carvalho; P.S. Pinheiro; N.O. Leiner; P.K. Lira; M.S.L. Figueiredo \& H.S.A. Carlos. 2006. Ecologia do marsupial Micoureus demerarae em fragmentos de Mata Atlântica no estado do Rio de Janeiro. In: T.R.O. Freitas; E. Vieira; S. Pacheco \& A. Christoff (Eds). Mamíferos do Brasil: genética, sistemática, ecologia e conservação. São Carlos, Suprema Gráfica e Editora, 176p.

FonsecA, G.A.B. 1985. The vanishing Brazilian Atlantic Forest. Biological Conservation 34: 17-34.

Foose, T.J. 1993. Riders of the last ark: the role of captive breeding in conservation strategies. In: L. KaUfMAN \& K. MALLORY (Eds). The last extinction. Cambridge, MIT Press and New England Aquarium, 250p.

Foose, T.J.; R. Lande; N.R. Flesness; G. Rabb \& B. Read. 1986. Propagation plans. Zoo Biology 5: 139-146.
Frankham, R. 1995. Effective population size/adult population size ratios in wildlife: a review. Genetic Research 66: 95-107.

FrankHam, R. 1996. Relationship of genetic variation to population size in wildlife. Conservation Biology 10: 15001508.

Frankham, R. 1998. Inbreeding and extinction: island populations. Conservation Biology 12: 665-675.

Frankham, R. \& B.W. Brook. 2004. The importance of time scale in conservation biology and ecology. Annales Zoologi Fennici 41: 459-463.

FrankLIN, I.R. 1980. Evolutionary change in small populations, p. 135-149. In: M.E. Soulé \& B. WILCOX (Eds). Conservation biology: an evolutionary-ecological perspective. Sunderland, Sinauer Associates, 395p.

Fuerst, P.A. \& T. Maruyama. 1986. Considerations on the conservation of alleles and of genic heterozygosity in small managed populations. Zoo Biology 5: 171-179

Gardner, A.L. 2005. Order Didelphimorphia, p. 3-18. In: D.E. Wilson DE \& D.A. Reeder (Eds). Mammal species of the world: a taxonomic and geographic reference. Baltimore, Johns Hopkins University Press, 2000p.

GibBs, J.P. 2001. Demography versus habitat fragmentation as determinants of genetic variation in wild populations. Biological Conservation 100: 15-20.

Gilpin, M.E. \& M.E. Soulé. 1986. Minimum viable populations: processes of extinction, p. 19-34. In: M.E. Soulé (Ed.). Conservation biology: the science of scarcity and diversity. Sunderland, Sinauer Associates, 584p.

Goulart, F.V.B.; F.L. Souza; H.B. Pavese \& M.E. Graipel. 2006. Estrutura populacional e uso do estrato vertical por Micoureus paraguayanus (Didelphimorphia, Didelphidae) em fragmentos de Floresta Atlântica no sul do Brasil. Biotemas 19: 4553.

Grelle, C.E.V. 2003. Forest structure and vertical stratification of small mammal populations in a secondary forest, southeastern Brazil. Studies on Neotropical Fauna and Environment 38: 81-85.

Hedrick, P.W. 2001. Conservation genetics: where are we now? Trends in Ecology and Evolution 16: 629-636.

Hedrick, P.W. \& S.T. KaLINOwsKi. 2000. Inbreeding depression in conservation biology. Annual Review of Ecology and Systematics 31: 139-162.

Higgins, K. \& M. LynCH. 2001. Metapopulation extinction caused by mutation accumulation. Proceedings of the National Academy of Science USA 98: 2928-2933.

Hirota, M.M. 2003. Monitoring the Brazilian Atlantic Forest cover, p. 60-65. In: C. Galindo-Leal \& I.G. CÂmara (Eds). The Atlantic Forest of South America: biodiversity status, threats and outlook. Washington, Island Press, 408p.

Ives, A.R. \& M.C. Whitlock. 2002. Inbreeding and metapopulations. Science 295: 454-455.

Keller, L.F. \& D.M. Waller. 2002. Inbreeding effects in wild populations. Trends in Ecology and Evolution 17: 230-241. 
LACY, R.C. 1987. Loss of genetic diversity from managed populations: interacting effects of drift, mutation, immigration, selection, and population subdivision. Conservation Biology 1: 143-158.

LACY, R.C. 1993a. Impacts of inbreeding in natural and captive populations of vertebrates: implications for conservation. Perspectives in Biology and Medicine 36: 480-496.

LACY, R.C. 1993b. Vortex: a computer simulation model for population viability analysis. Wildlife Research 20: 45-65.

LACY, R.C. 1997. Importance of genetic variation to the viability of mammalian populations. Journal of Mammalogy 78: 320-335.

LACY, R.C. 2000. Structure of the Vortex simulation model for population viability analysis. Ecological Bulletin 48: 191203.

LACY, R.C. \& J.D. Ballou. 1998. Effectiveness of selection in reducing the genetic load in populations of Peromyscus polionotus during generations of inbreeding. Evolution 52: 900-909.

LACY, R.C. \& D.B. Lindenmayer. 1995. A simulation study of the impacts of population subdivision on the mountain brushtail possum Trichosurus caninus Ogilby (Phalangeridae: Marsupialia), in south-eastern Australia. II. Loss of genetic variation within and between subpopulations. Biological Conservation 73: 131-142.

LANDE, R. 1995. Mutation and conservation. Conservation Biology 9: 782-791.

LANDE, R. \& G.F. Barrowclough. 1987. Effective population size, genetic variation, and their use in population management, p. 87-123. In: M.E. Soulé (Ed.). Viable populations for conservation. Cambridge, Cambridge University Press, 204p.

LEDIG, F.T. 1992. Human impacts on genetic diversity in forest ecosystems. Oikos 63: 87-108.

Leite, Y.L.; J. Stallings \& L.P. Costa. 1994. Partição de recursos entre espécies simpátricas de marsupiais na Reserva Biológica de Poços das Antas, Rio de Janeiro. Brazilian Journal of Biology 54: 525-536.

LindenMAYER, D.B. \& R.C. LACY. 1995. A simulation study of the impacts of population subdivision on the mountain brushtail possum Trichosurus caninus Ogilby (Phalangeridae: Marsupialia) in south-eastern Australia. I. Demographic stability and population persistence. Biological Conservation 73: 119-129.

Lindenmayer, D.B.; M.A. Burgman; H.R. AKÇaKaya; R.C. LaCy \& H.P. Possingham 1995. A review of the generic computer programs Alex, Ramas/space and Vortex for modelling the viability of wildlife metapopulations. Ecological Modelling 82: 161-174.

Maruyama, T. \& P.A. Fuerst. 1985. Population bottlenecks and non-equilibrium models in population genetics, II. Number o alleles in a small population that was formed by a recent bottleneck. Genetics 111: 675-689.
Maruyama, T. \& M. Kimura. 1980. Genetic variability and effective population size when local extinction and re-colonization of sub-populations are frequent. Proceedings of the National Academy of Science USA 77: 6710-6714.

Miller, P.S. \& R.C. LACY 2005. Vortex: a stochastic simulation of the extinction process. Version 9.50 user's manual. Apple Valley, Conservation Breeding Specialist Group (CBSGSSC/IUCN),

Miller, P.S. \& P.W. Hedrick. 1993. Inbreeding and fitness in captive populations: lessons from Drosophila. Zoo Biology 12: 333-351.

Miller, P.S. \& P.W. Hedrick. 2001. Purging of inbreeding depression and fitness decline in bottlenecked populations of Drosophila melanogaster. Journal of Evolutionary Biology 14: 595-601.

Mills, L.S. \& F.W. Allendorf. 1996. The one-migrant-pergeneration rule in conservation and management. Conservation Biology 10: 1509-1518.

Mills, L.S. \& P.E. Smouse. 1994. Demographic consequences of inbreeding in remnant populations. American Naturalist 144: $412-431$.

Mittermeier, R.A.; P.R. Gil; M. Hoffmann; J. Pilgrim; T. Brooks; C.G. Mittermeier; J. Lamoreux \& G.A.B. da Fonseca. 2005. Hotspots revisited: earth's biologically richest and most threatened terrestrial ecoregions. CEMEX, Mexico City.

Moraes, E.A. \& A.G. Chiarello. 2005a. A radio tracking study of home range and movements of the marsupial Micoureus demerarae (Thomas) (Mammalia, Didelphidae) in the Atlantic Forest of south-eastern Brazil. Revista Brasileira de Zoologia 22: 85-91.

Moraes, E.A. \& A.G. Chiarello. 2005b. Sleeping sites of woolly mouse opossum Micoureus demerarae (Thomas) (Didelphimorphia, Didelphidae) in the Atlantic Forest of south-eastern Brazil. Revista Brasileira de Zoologia 22: 839843.

Myers, N.; R.A. Mittermeier; C.G. Mittermeier; G.A.B. DA FonsecA $\&$ J. Kent. 2000. Biodiversity hotspots for conservation priorities. Nature 403: 853-858.

PASSAMANI, M. 1995. Vertical stratification of small mammals in Atlantic hill forest. Mammalia 59: 276-279.

Passamani, M. 2000. Community analyses of marsupials in the Atlantic Forest of Santa Teresa, Espírito Santo, Brazil. Boletim do Museu de Biologia Mello Leitão 11/12: 215-228.

Pinheiro, P.S.; F.M.V. Carvalho; F.A.S. Fernandez \& J.L. Nessimian. 2002. Diet of the marsupial Micoureus demerarae in small fragments of Atlantic Forest in southeastern Brazil. Studies on Neotropical Fauna and Environment 37: 213-218.

Pires, A.S. \& F.A.S. Fernandez. 1999. Use of space by the marsupial Micoureus demerarae in small Atlantic Forest fragments in south-eastern Brazil. Journal of Tropical Ecology 15: 279-290.

Pires, A.S.; F.A.S. Fernandez \& D. Freitas. 1999. Patterns of space use by Micoureus demerarae (Marsupialia: Didelphidae) in a 
fragment of Atlantic Forest in Brazil. Mastozoologia Neotropical 6: 39-45.

Pires, A.S.; P.K. Lira; F.A.S. Fernandez; G.M. Schittini \& L.C. OliVEIRA. 2002. Frequency of movements of small mammals among Atlantic Coastal Forest fragments in Brazil. Biological Conservation 108: 229-237.

Quental, T.B.; F.A.S. Fernandez; A.T.C. Dias \& F.S. Rocha. 2001. Population dynamics of the marsupial Micoureus demerarae in small fragments of Atlantic Coastal Forest in Brazil. Journal of Tropical Ecology 17: 339-352.

Ralls, K.; J.D. Ballou \& A. Templeton. 1988. Estimates of lethal equivalents and the cost of inbreeding in mammals. Conservation Biology 2: 185-193.

ReED, D.H. 2004. Extinction risk in fragmented habitats. Animal Conservation 7: 181-191.

Rodrigues, F.P.; F.S. Rocha; J.E. Garcia; J.F. Garcia; M. Vivo \& S.R. Matioli. 2006. Isolation and characterization of microsatellite loci in the woolly mouse opossum, Micoureus paraguayanus (Marsupialia: Didelphimorphia). Molecular Ecology Notes 6: 686-688.
Shaffer, M.L. 1981. Minimum population sizes for species conservation. BioScience 31: 131-134.

Simberloff, D. 1988. The contribution of population and community biology to conservation science. Annual Reviews of Ecology and Systematics 19: 473-511.

Soulé, M.E. 1987. Viable populations for conservation. Cambridge University Press, Cambridge.

Soulé, M.E. \& L.S. Mills. 1998. No need to isolate genetics. Science 282: 1658-1659.

Templeton, A.R. \& B. ReAD. 1984. Factors eliminating inbreeding depression in a captive herd of Speke's gazelle. Zoo Biology 3: 177-199.

VAN VALEN, L. 1973. A new evolutionary law. Evolutionary Theory 1: 1-30.

Vario, S.L.; R. Chakraborty \& M. Nei. 1986. Genetic variation in subdivided populations and conservation genetics. Heredity 57: 189-198.

VucEtich, J.A. \& T.A. WAITE. 2000. Is one migrant per generation sufficient for the genetic management of fluctuating populations? Animal Conservation 3: 261-266.

Submitted: 22.XI.2008; Accepted: 11.XII.2009.

Editorial responsibility: Marcio R. Pie 